\title{
The Evaluation Of Slums Level In Jatibarang, Semarang
}

\author{
Masitoh Ernawati ${ }^{1 *}$, Kismartini Kismartini ${ }^{2}$, and Maryono Maryono ${ }^{3}$ \\ ${ }^{1}$ Master Program of Environmental Science, Diponegoro University, Semarang - Indonesia \\ ${ }^{2}$ Department of Public Administration, Diponegoro University, Semarang-Indonesia \\ ${ }^{3}$ Department of Urban and Regional Planning, Diponegoro University, Semarang - Indonesia
}

\begin{abstract}
One of the village that get first priority in slums handling in in Semarang City based on mayor decree of Semarang's number 050/801/2014 is Jatibarang Village. According the Ministry of Public Works through the KOTAKU (Kota Tanpa Kumuh) Program, in 2017 Jatibarang Village received funding for road and drainage construction. This research is to evaluate the slum reduction of road and drainage construction in a neighborhood. The method of research is quantitative and comparative through data calculation on 2 (two) criteria after handling and comparied with baseline data. Based on the results of the research it can be seen that the slum handling of 2 (two) slum criteria did not give big impact to the slum value that is 40 before the handling and 30 after handling with the difference of 10 points. The results of this research indicate that there is still a need for handling slum reduction in this area. It is also necessary to evaluate the value of slum periodically of slum areas that have been set in order to know the changes that occur. involving the local community in the maintenance of settlement environment is necessary as well, so it is expected that the slum reduction increases, insteade of decreasing..
\end{abstract}

Keywords: slums; slum value; KOTAKU

\section{Introduction}

In the United Nations Millennium Declaration, world leaders has set the specific goal of achieving 'significant improvement in the lives of at least 100 million slum dwellers by the year 2020' [1]. The United Nations System assigns UN-HABITAT to help realize the goals of the Millennium Declaration, as a responsibility to help the government monitor and gradually reach the "Cities Without Slums" Target [2].

The poor quality of the settlement environment is one of the causes of the increase in carbon gas emissions. The impacts that occur are significant climate change and the occurrence of natural disasters such as floods and so on.

To reduce slums and improve the lives of slum dwellers, many national and city governments and international financial institutions have programs aimed at addressing the growing problems of slums [3]. Slum upgrading is conducted through concerted strategies and involves self-help and local ownership as the recommended response to poor conditions and services in existing slums [1].

In Indonesia, prevention and improvement of the slums quality have been mandated in Act Number 1
Year 2011 on Housing and Settlement Areas [4]. In addition, the handling of slums has been clearly targeted to the RPJMN 2015-2019. The achievement is 0 percent urban slum settlement through the handling of slum areas[5].

The Decree of Mayor of Semarang number 050/801/2014 about the location of residential neighborhood and slum settlement of Semarang City has been decided 415,83 ha or $4,16 \mathrm{~km} 2$ or reaching $1,11 \%$ from Semarang City area[6]. One of village thats gets priority in slums handling Semarang City is Jatibarang Village. The location of the slums of Jatibarang slums located at $\mathrm{rt} 4 \mathrm{rw} 2 \mathrm{which}$ is classified as light with $0.86 \mathrm{Ha}$ area[7].

The government through the Ministry of Public Works conduct the handling of slum settlement in Jatibarang Village. Handling was done in 2017 with the efforts to improve environmental quality through the road and drainage construction.

Improving the quality of the environment in slums is expected to be one of the Government's efforts in tackling climate change through funding instruments to improve the quality of the environment of national slums and Low Carbon Development Planning. 
Based on the things that have been mentioned above, then the subject of this research problem can be formulated as follows:

1. Will the road and drainage of the environment solve the slum problems?

2. How big is the impact of this treatment on the slum?

This research aims to :

1. Evaluate the slums based on the 2 slum criteria that are road and drainage.

2. Compare the value of slum level before and after the handling.

\section{Metodology}

This research used quantitative and comparative method. The result of the calculation will produce a matrix for then to be comparated to the initial and final variables.

Quantitative research is a reseach conducted by obtaining data in the form of numbers or qualitative data suspected[8]. Quantitative approaches emphasize objective phenomena to be studied quantitatively.[9]
The steps in this study were to conduct field surveys, collect data and search for appropriate data sources, determine the number of population and sample to be selected as respondents, describe the indicator variable.

The infrastructure variables in the slum areas measured include:(1) environmental road conditions;(2) Condition of water supply drink;(3) environmental drainage conditions (4) Condition of waste management; and (5) Condition of fire protection.

\section{Result}

\subsection{Slum Settlement of Jatibarang Village}

Slum settlements are unfit settlements because of building irregularity, high building density, and quality of buildings and facilities that are not qualified.[10]

Determination of slum location in Jatibarang Village in accordance to the Decree of Mayor of Semarang Number 050/801/2014 about the location of residential neighborhood and slum settlement of Semarang city is RT 4 RW 2 with an area of $0,86 \mathrm{Ha}$.

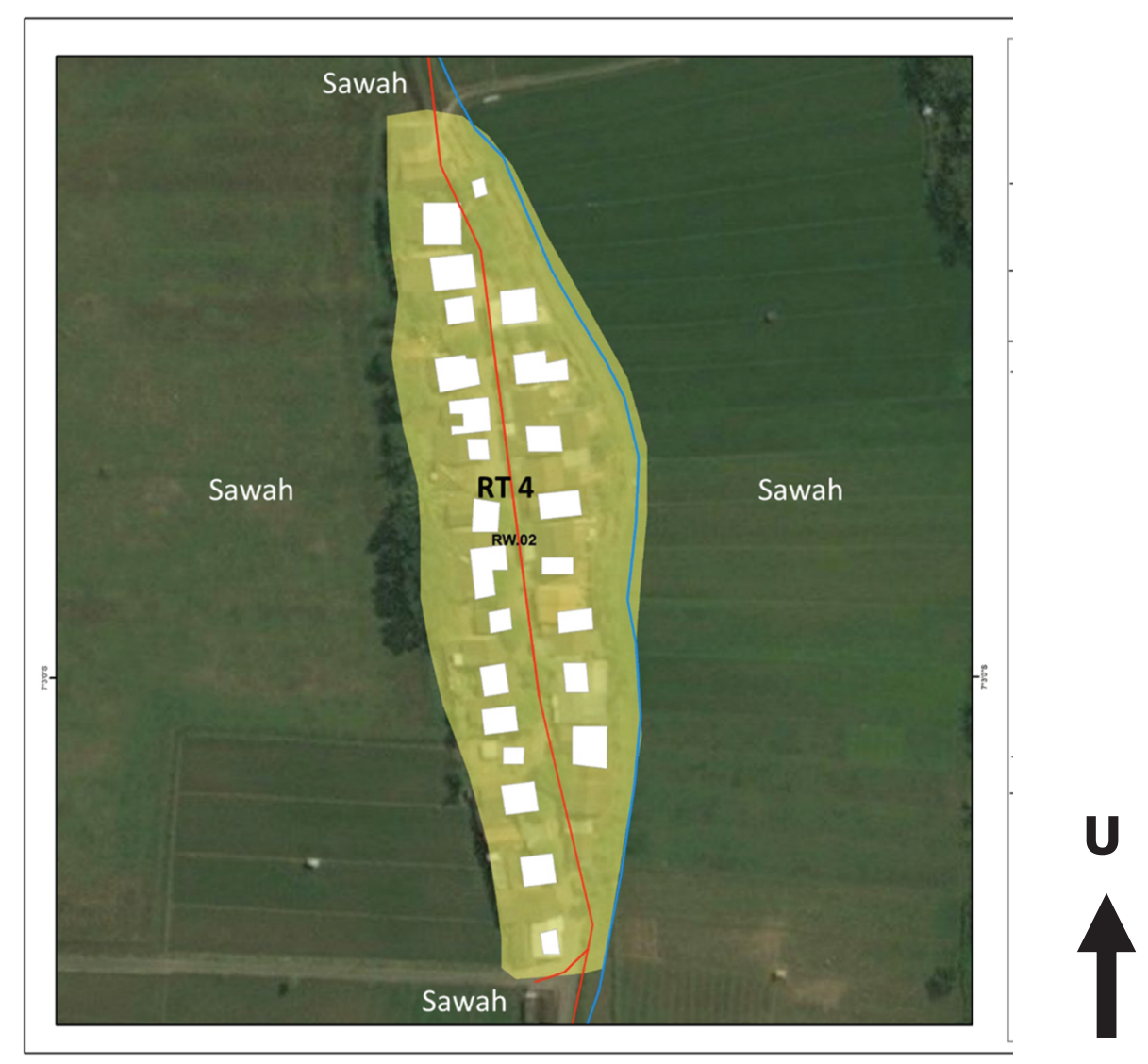

Fig 1. Slums Location Map of Jatibarang Village

Characteristic of slum in Jatibarang Village is slum settlement in hilly areas where majority of residential buildings do not have IMB (Permits Building
License)[7]. The typology of the hill slum is slum housing and slum settlements located in upland areas with a slope of $>10 \%$ and $<40 \%$.[10] 
With the existing problems that is :

a. Road network conditions, it is recorded 200 meters of road network is damaged and poor condition.

b. Drainage conditions, a total of 638 meters long recorded the need for new drainage channels because most of the slum areas do not have drainage channels.

c. Clean water, is that almost all areas are served by clean water through the existence of shallow wells owned by each house, but the clean water is not enough to meet the needs of the community in the dry season. d. waste management, is the absence of management systems and infrastructure facilities supporting waste management. The garbage generated from each house is mostly trown or burned on vacant lot.

e. Fire protection, there hasn't been fire protection facilities and infrastructure. [7]

The problem data was obtained through baseline data that was converted to be the data according to the parameters of each criterion and is scored so that got in order to get the slum value before handling.

Table 1. Slum Score Problem Before The Handling

\begin{tabular}{|c|c|c|c|}
\hline \multirow[t]{2}{*}{ Aspect } & \multirow[t]{2}{*}{ Criteria } & \multicolumn{2}{|c|}{$\begin{array}{l}\text { Initial condition } \\
\text { (before handling) }\end{array}$} \\
\hline & & Prosen $(\%)$ & Value \\
\hline $\begin{array}{l}\text { 1. Road Condition in the } \\
\text { Neighborhood }\end{array}$ & a. Quality Road Surface environment & $90,91 \%$ & 5 \\
\hline 2. Availability of Drinking Water & $\begin{array}{l}\text { a. Not fulfilled the needs of drinking } \\
\text { water }\end{array}$ & $100,00 \%$ & 5 \\
\hline $\begin{array}{l}\text { 3. Drainage Condition in the } \\
\text { Neighborhood }\end{array}$ & a. Drainage Unavailability & $76,13 \%$ & 5 \\
\hline \multirow[t]{3}{*}{4 Waste Management Condition } & $\begin{array}{l}\text { a. Waste disposal Facility and } \\
\text { Infrastructure unsuitable Technical } \\
\text { Requirements }\end{array}$ & $100,00 \%$ & 5 \\
\hline & $\begin{array}{l}\text { b. Waste disposal Management system } \\
\text { unsuitable Technical Standart }\end{array}$ & $100,00 \%$ & 5 \\
\hline & $\begin{array}{l}\text { c. Unsanitary of Waste Management } \\
\text { Facility and Infrastructure }\end{array}$ & $100,00 \%$ & 5 \\
\hline \multirow[t]{2}{*}{ 5. Fire Protection Condition } & $\begin{array}{l}\text { a. Unavailability of Fire Protection } \\
\text { Infrastructure }\end{array}$ & $100,00 \%$ & 5 \\
\hline & $\begin{array}{l}\text { b. Unavailability of Fire Protection } \\
\text { Facilities }\end{array}$ & $100,00 \%$ & 5 \\
\hline & & TOTAL & 40 \\
\hline & & $\begin{array}{l}\text { SLUM } \\
\text { LEVEL }\end{array}$ & $\begin{array}{l}\text { lighte } \\
\text { r slum }\end{array}$ \\
\hline
\end{tabular}

\subsection{Handling of slums}

In the year 2017 slum handling conducted by the Ministry of public works through KOTAKU (Kota Tanpa Kumuh) program was the construction of Road along the $200 \mathrm{~m}$ and Drainage along $673 \mathrm{~m}$ in Jatibarang Village. From the data of the handling, the value of baseline data for the two slum categories reviewed in this study changed its value to the value after handling and then converted into slum reduction data and slum scoring. This study will analysis condition of slums area according to to program achievement, challenging and people understanding dou to program impact concerning the program that have been run in the location study

\subsection{Comparison of Slum Values}

Based on the baseline data that has been converted, we can compare the slum data based on the baseline data with baseline data post-handling, so that the slum changes can be understood.

From the data of slum area handling on two slum criteria, namely road and drainage, there is difference value, on the neighborhood road surface quality parameter where from the initial data was 5 (76\% $100 \%$ of area had poor road surface quality), and after handling the value changed to 0 because the area has good road surface quality as can be seen. On the 
drainage unavailibilty parameter where from the initial data was $5(76 \%-100 \%$ of the area has not been provided with neighborhood drainage), and after handling the value changed to 0 because the area had drainage available, as can be seen in the following table.

Table 2. Slums Value Reduction in Jatiibarang Village

\begin{tabular}{|c|c|c|c|c|c|}
\hline \multirow[t]{2}{*}{ Aspect } & \multirow[t]{2}{*}{ Criteria } & \multicolumn{2}{|c|}{$\begin{array}{l}\text { Initial condition } \\
\text { (before handling) }\end{array}$} & \multicolumn{2}{|c|}{$\begin{array}{l}\text { Final condition } \\
\text { (after handling) }\end{array}$} \\
\hline & & Prosen (\%) & Value & Prosen (\%) & Value \\
\hline $\begin{array}{l}\text { 1. Road Condition in the } \\
\text { Neighborhood }\end{array}$ & $\begin{array}{l}\text { a. Quality Road Surface } \\
\text { environment }\end{array}$ & $90,91 \%$ & 5 & $0,00 \%$ & 0 \\
\hline 2. Availability of Drinking Water & $\begin{array}{l}\text { a. Not fulfilled the needs of } \\
\text { drinking water }\end{array}$ & $100,00 \%$ & 5 & $100,00 \%$ & 5 \\
\hline $\begin{array}{l}\text { 3. Drainage Condition in the } \\
\text { Neighborhood }\end{array}$ & a. Drainage Unavailability & $76,13 \%$ & 5 & $23,87 \%$ & 0 \\
\hline \multirow[t]{3}{*}{ 4. Waste Management Condition } & $\begin{array}{l}\text { a. Waste disposal Facility and } \\
\text { Infrastructure unsuitable } \\
\text { Technical Requirements }\end{array}$ & $100,00 \%$ & 5 & $100,00 \%$ & 5 \\
\hline & $\begin{array}{l}\text { b. Waste disposal Management } \\
\text { system unsuitable Technical } \\
\text { Standart }\end{array}$ & $100,00 \%$ & 5 & $100,00 \%$ & 5 \\
\hline & $\begin{array}{l}\text { c. Unsanitary of Waste } \\
\text { Management Facility and } \\
\text { Infrastructure }\end{array}$ & $100,00 \%$ & 5 & $100,00 \%$ & 5 \\
\hline \multirow[t]{2}{*}{ 5. Fire Protection Condition } & $\begin{array}{l}\text { a. Unavailability of Fire Protection } \\
\text { Infrastructure }\end{array}$ & $100,00 \%$ & 5 & $100,00 \%$ & 5 \\
\hline & $\begin{array}{l}\text { b. Unavailability of Fire } \\
\text { Protection Facilities }\end{array}$ & $100,00 \%$ & 5 & $100,00 \%$ & 5 \\
\hline & & TOTAL & 40 & TOTAL & 30 \\
\hline & & $\begin{array}{l}\text { SLUM } \\
\text { LEVEL }\end{array}$ & $\begin{array}{l}\text { lighte } \\
r \text { slum }\end{array}$ & $\begin{array}{l}\text { SLUM } \\
\text { LEVEL }\end{array}$ & $\begin{array}{l}\text { lighte } \\
\text { r slum }\end{array}$ \\
\hline
\end{tabular}

From the table above, the slum value of Jatibarang Village prior to the slum handling is 40 which is categorited in the range of Light Slums. After the handling of the two slum criteria that were the road and drainage there is a change of value in this area from 30 , categooried as light slum range. There was a difference of 10 points.

\section{Conclusion}

Based on the results of research in the previous chapter, it can be concluded that:

1. The handling of slum areas based on 2 (two) slum criteria that have been implemented in Jatibarang Village is Road and Drainage. The handlinng did not give big impact to the slum as stated in the Decree of Mayor of Semarang Number 050/801/2014.

2. Change in the slum value of Jatibarang Village was 40 before handling of 40 and 30 after the handling of neighborhood Road and Drainage, resulting in a reduction of 10 points.

\section{ACKNOWLEDGMENT}

Part of this research is funded by the Directorate of Research and Community Services, Ministry of Research, Technology and Higher Education for year 2018 with contract number 101-147/UN7.P4.3/PP/2018.

\section{References}

1. Un-Habitat, The Challenge of Slums: Global Report on Human Settlements 2003, (2003)

2 UN-Habitat, Slums of the World: The Face of urban poverty in the new millennium?, (2003)

3. S. V. Dasgupta, Basab and Lall, Assessing Benefits Of Slum Upgrading Programs In Second-Best Setting, Dev. Res. Group, World Bank, Washingt. DC 20433, no. WPS3993, pp. 1-40, (2006)

4. D. Noris et al., Kajian Perubahan Tingkat Kekumuhan Pasca Penanganan Kawasan Kumuh Cot Bak U, Kota Sabang Provinsi Aceh, J. Tek. SIpil Univ. Syiah Kuala, vol. 1, no. Nomor 2, Desember,2017, pp. 359-370, 
(2017)

5. BPPN, Lampiran Peraturan Presiden Republik Indonesia Nomor 2 Tahun 2015 Tentang Rencana Pembangunan Jangka Menengah (RPJMN) tahun 2015-2019: Agenda Pembangunan Nasional, (2014)

6. Pemerintah Kota Semarang, Peraturan Daerah Kota Semarang Nomor 11 Tahun 2017 Tentang Perubahan Atas Peraturan Daerah Kota Semarang Nomor 6 Tahun 2016 Tentang Rencana Pembangunan Jangka Menengah Daerah Kota Semarang Tahun 2016-2021, (2017)

7. K. Kota Semarang, Profil Kawasan Kumuh Kelurahan Jatibarang, Project By KOTAKU (Kotaku Tanpa Kumuh) Kota Semarang, (2017)
8. Sugiyono, Metode Penelitian Pendidikan: Pendekatan Kuantitatif, Kualitatif, dan R\&D. Bandung: Alfabeta, (2013)

9. E. Hamdi,Asep Saepul dan Bahruddin, Metode Penelitian Kuantitatif Aplikasi Dalam Pendidikan, Yogyakarta: DEEPUBLISH, (2012)

10. Menteri Pekerjaan Umum dan Perumahan Rakyat, Peraturan Menteri Pekerjaan Umum dan Perumahan Rakyat Nomor 02 Tahun 2016 tentang Kualitas Terhadap Perumahan Kumuh dan Permukiman Kumuh. Kementerian Pekerjaan Umum Dan Perumahan Rakyat, Kementeri. Pekerj. Umum dan Perumah. Rakyat, pp. 1-36, (2016) 